\title{
IMPIEDADES REVELADAS: HISTÓRIAS DE VALORES MORAIS E POLÍTICOS PARA EXEMPLO E PROVEITO DOS GOVERNANTES, SEGUNDO ALGUMAS LIÇÕES DE MAQUIAVEL
}

\author{
Marcos Antônio LOPES ${ }^{1}$
}

Recibido: 08/05/2012

Aceptado: 08/10/2012

RESUMO: Análise centrada em aspectos mais conservadores nos textos de Maquiavel, que o realçam bem mais como seguidor de uma tradição antiga de se pensar a política, do que como o ilustre fundador da Ciência Política moderna. Essa visada teórica encontra base empírica sólida em sua concepção do gênero Specula principum, que Maquiavel preservou à sua maneira e que atesta a sua identificação com valores culturais do passado, em contraste com a sua moderna concepção da ação política.

PALAVRAS-CHAVE: História das Ideias; Maquiavel; Intelectuais e Poder; Sabedoria Política.

ABSTRACT: Analysis centered in more conservative aspects in the Maquiavel's texts, that enhance it very more as follower of an old tradition of thinking the politics, that as the illustrious founder of the modern Political Science. This theoretical conception finds solid empiric base in its conception of the gender Specula principum, that Machiavelli preserved and that he attests its identification with cultural values of the past, in contrast with its modern conception of the political action.

KEYWORDS: History of Ideas; Machiavelli; Intellectuals and Power; Political Wisdom.

Deve o príncipe ter muito cuidado para que suas palavras nunca deixem de refletir as cinco qualidades acima indicadas, de forma que quem o veja e ouça pense ser todo ele piedade, fé, integridade, humanidade e religião. (...) Isto porque, se se refletir bem será fácil perceber que certas qualidades que parecem virtudes levam à ruína, e outras que parecem vícios trazem como resultado o aumento da segurança e do bem-estar.

Maquiavel (O Príncipe)

\footnotetext{
${ }^{1}$ Doutor em História pela Universidade de São Paulo. Professor da Universidade Estadual de Londrina. Pesquisador do Conselho Nacional de Desenvolvimento Científico e Tecnológico/Brasil.
} 
O bem e o mal são nomes que significam nossos apetites e aversões, os quais são diferentes conforme os diferentes temperamentos, costumes e doutrinas dos homens. E homens diversos não divergem apenas, em seu julgamento, quanto às sensações do que é agradável ou desagradável ao gosto, ao olfato, ao ouvido, ao tato e à vista, divergem também quanto ao que é conforme ou desagradável à razão, nas ações da vida cotidiana. Mais, o mesmo homem, em momentos diferentes, diverge de si mesmo, às vezes louvando, isto é, chamando bom, àquilo mesmo que outras vezes despreza e que chama mau.

\section{Thomas HoBBES (Leviatã)}

Maquiavel possuía uma clara consciência dos novos enfoques que iria propor no campo da reflexão intelectual acerca da ação política. Quanto a essa nova sabedoria política, o décimo quinto capítulo de $O$ Príncipe é muito eloquente. Nesse capítulo, ele dá mostras de que se orgulha em desafinar do tom habitual de apresentar a política e, ao que parece, tinha consciência de ser um divisor de águas.

"Como sei que muitos já escreveram sobre o assunto temo que estas palavras possam parecer presunçosas, por discreparem, especialmente neste ponto, das opiniões de outras pessoas". 2

A operação intelectual que ele realizou com notável grau de originalidade consistiu no fato de ter colocado a política na posição em que está até hoje. Robert Chrisholm avalia a dessacralização da política empreendida por Maquiavel considerando que Maquiavel não se interessou verdadeiramente pelas tradições da filosofia moral. Contudo, não fechou suas vistas para as sutis diferenças entre bem e mal. E prossegue Chrisholm avaliando que o sistema de avaliação do autor fundase num princípio virtuoso que ele enxergava como capital: "o estabelecimento da ordem temporal". 3 Talvez por isso, a influência do historiador de Florença foi marcante através dos séculos. A difusão de $O$ Príncipe, lembra Isaiah Berlin, gerou nada menos do que vinte "famílias" interpretativas importantes. E esse cipoal de perspectivas, além de já bastante vasto, cresce muito rapidamente. ${ }^{4}$

${ }^{2}$ Maquiavel, Nicolau. Maquiavel, O Príncipe - Estudos. Brasília: Editora UnB, 1982. p. 64.

${ }^{3}$ Chrisholm, Robert. «A ética feroz de Maquiavel». In: Quirino, Célia. et AliI. (Org.). Clássicos do pensamento político. São Paulo: Edusp/Fapesp, 1998. p. 73.

${ }^{4} C f$. Berlin, Isaiah. «La originalidad de Maquiavelo». In: _. Contra la corriente. Ensayos sobre historia de las ideas. México: FCE, 1992. p. 85. A primeira versão do texto «The Originality of Machiavelli», de Berlin, data de 1953. 
Maquiavel se vangloriava de ter descoberto um "novo continente moral", dizia Leo Strauss, e comparava a magnitude de suas descobertas com as de Colombo. ${ }^{5}$ De fato, ele rompeu a unidade do pensamento político ocidental, que tinha como seus temas centrais as relações entre a Igreja e o Estado, bem como a arte de governar, segundo o prisma das virtudes cristãs. De acordo com Raymond Gettell, Maquiavel não deu atenção às pretensões da Igreja relativamente ao Estado, ou do Papa em relação ao concílio, nem aos ensinamentos das Sagradas Escrituras, nem às opiniões dos Santos Padres, nem mesmo aos princípios do direito natural. ${ }^{6}$ Assim sendo, Maquiavel representa um importante foco de fissura no processo de secularização do pensamento político ocidental, processo que havia sido cristianizado ao longo de mais de mil anos de história, e que continuou sob os signos e emblemas da moral cristã séculos após Maquiavel ter concebido a sua obra.

Nos reinos cristãos do início da Época Moderna, a política era concebida como vestal imaculada por parte de clérigos, reis e imperadores, como se tratasse do reino ideal para o exercício das virtudes mais puras. Em seus textos, Maquiavel contrariou a lógica do pensamento político de seu tempo, e o maquiavelismo continuou sendo crítico da lógica predominante na política da Época Moderna muito tempo depois dele ter explicitado os seus "novos" contornos. No século XVIII, Voltaire afirmou que o veneno de Maquiavel era demasiadamente público, e seria preciso que o antídoto também o fosse. Avaliando uma obra política de ilustre autoria, Voltaire reputou-a melhor pensada e escrita que o livro de Maquiavel, e calculou que seria uma felicidade para o gênero humano, enfim, assistir a virtude melhor ornada que o vício. ${ }^{7}$ A avaliação de Voltaire demonstra uma dentre as inúmeras reações que, sobretudo, $O$ Príncipe provocou, séculos após sua publicação. De fato, o antimaquiavelismo foi uma força poderosa entre os escritores modernos, e Voltaire, ao escrever uma louvação ao Anti-Maquiavel, de autoria do príncipe prussiano Frederico II, demonstrou o engajamento que os textos do autor de Florença sempre gerou. No século XVII, Bossuet havia escrito dois livros nos quais se verifica um ataque sistemático ao pensamento de Maquiavel. ${ }^{8}$

${ }^{5}$ Cf. STRauss, Leo.What is Political Philosophy? New York: Free Press, 1968.

${ }^{6}$ Cf. GetTell, Raymond. História das ideias políticas. Lisboa: Editorial Inquérito, 1950. p. 165.

${ }^{7}$ Cf. Pomeau, René. «Présentation». In: —_. Politique de Voltaire. Paris: Armand Colin, 1994.

${ }^{8}$ Cf. BossuEt, Jacques-Bénigne. Discours sur l'Histoire Universel. Paris: Flammarion, 1920;.e Politique tirée des propres paroles de l'Ecriture Sainte. Genève, Droz, 1967, livros concebidos na época do preceptorado do filho de Luís XIV, ao longo das duas últimas décadas do século XVII. 
Mas, importa mesmo é afirmar que a descoberta de Maquiavel, o elemento de originalidade que fez a sua glória na história da reflexão filosófica, certamente deve ser identificada com a "fratura" que promoveu na aliança entre a religião e a política. A hostilidade que ele devotou à Igreja se explica pelo fato de ter acreditado que os padres destruíram a religião, impossibilitando que ela fosse utilizada como instrumento de condução das almas ao exercício pleno das virtudes cívicas. Nos Discorsi há passagens muito elucidativas a esse respeito, como quando escreve que "se se levasse em conta que a fé permite a grandeza e a defesa da pátria, ver-se-ia que é compatível com a boa religião amar e honrar a pátria, e nos prepararíamos para defendê-la". ${ }^{9}$ A corrupção da Igreja e a descrença crescente dos clérigos esvaziaram o sentimento religioso dos fiéis. De mais a mais, a consagração cristã do ideal de vida contemplativa contrariava a lógica da ação necessária, do estado de alerta permanente, que o príncipe deveria manter em guarda. Uma autêntica religião cívica deveria fomentar o temor e o respeito adequados à autoridade, e ajudar a inculcar o valor militar nos membros de uma comunidade política. Segundo Maquiavel, o manejo que a Igreja fez da religião, em vez de transformá-la em instrumento de mobilização nacional, levou a uma efeminação do mundo.

"Parece que esta moral nova", escreveu, "tornou os homens mais fracos, entregando o mundo à audácia dos celerados. Estes sabem que podem exercer sem medo a tirania, vendo os homens prontos a sofrer sem vingança todos os ultrajes, na esperança de conquistar o paraíso".

Entre outros argumentos acerca da superioridade dos antigos sobre os modernos em matéria religiosa, é o que se lê nos Comentários sobre a Primeira Década de Tito Lívio. ${ }^{10} \mathrm{O}$ critério do valor de uma religião é o papel que desempenha como promotora da solidariedade entre os homens. O enfraquecimento dos laços comunitários é fator demonstrativo de uma parte da corrupção e da decadência geral. Segundo Maquiavel, não há necessidade de que a religião se apóie na verdade, desde que ela seja uma força socialmente eficaz. ${ }^{11}$

No texto A liberdade do homem cristão, de 1520, Lutero caracterizou a Igreja de seu tempo como "O mais desregrado covil de ladrões, o mais vergonhoso de

${ }^{9}$ MaQuiavel, Nicolau. Comentários sobre a Primeira Década de Tito Livio. Brasília: Editora UnB, 1979. p. 206.

${ }^{10}$ Maquiavel, Nicolau. Comentários sobre a Primeira Década de Tito Livio. Op. cit., p. 207.

${ }^{11} C f$. BERLIN, Isaiah. «La originalidad de Maquiavelo». In: —. Op. cit.,p. 97. 
todos os bordéis, o próprio reino do pecado, da morte e do inferno". ${ }^{12}$ Maquiavel não tinha opinião muito diferente e, em análise menos dogmática, havia apontado a presença da Igreja na Itália como um sério problema para a constituição de um Estado nacional autônomo. Tal presença era uma influência nociva devido à sua natureza paradoxal, qual seja, ser forte demais para impedir a centralização política e a constituição de uma unidade nacional, e fraca demais caso lhe interessasse empreendê-las. Deriva dessa avaliação o seu desejo de assistir ao advento de uma Itália livre da ação dos clérigos, que fizeram dos homens seres descrentes e divididos. Para ele, a Igreja era uma cidadela da ineficácia, visão que aproxima o ideal maquiaveliano das concepções iluministas de secularização da vida social.

Sem dúvida, o pensamento de Maquiavel deu sentido e expressão a algo que os homens já conheciam por intuição e por experiência, mas que ninguém havia ousado reconhecer de uma maneira sistemática. Como afirmou um historiador do pensamento científico, Maquiavel não aspirava criar uma nova lógica. Simplesmente pôs a funcionar uma lógica que, na prática, era admitida de longa data. O imoralismo de Maquiavel é pura lógica. ${ }^{13}$ Isso equivale a dizer que o maquiavelismo político é anterior ao próprio Maquiavel, que teria sido uma espécie de codificador de princípios capazes de conduzir a ação política de forma mais resoluta e eficaz. É de fato interessante pensar que o historiador de Florença não inventou o maquiavelismo, apesar de tê-lo compilado em $O$ Príncipe com todos os traços de originalidade autoral que se lhe reconhece.

Maquiavel é autor de vários livros, os mais importantes produzidos num mesmo espírito, o que vale dizer, concebidos sob as mesmas coerções políticas, sociais, econômicas e, também, sob o imperativo categórico de questões mais prosaicas de sua vida privada. No dizer de Norberto Bobbio, ele é "o mais político dos escritores políticos". Com efeito, o exercício da política era-lhe mais atrativo do que as questões filosóficas; as articulações e os tentáculos do poder, enfim, a maquinaria do governo, das forças orientadoras que instruíam a sua atuação, despertavam-lhe maior curiosidade do que abstrações acerca da natureza do Estado.

Por isso mesmo, ele protagonizou um dos mais curiosos e dramáticos capítulos da história dos escritores, em suas relações com o poder político. Sua história de vida foi, em parte, uma sucessão de investidas malogradas para recuperar um posto na administração do Estado, o ofício na Segunda Chancelaria da República de

12 Citado em Perry, Marvin. Civilização Ocidental: uma história concisa. São Paulo: Martins Fontes, 1999. p. 234.

${ }^{13}$ Cf. KoYRÉ, Alexandre. Estudos de história do pensamento científico. Brasília: Editora UnB, 1982. 
Florença, bem como o papel de Conselheiro de Estado, o que representava para os homens de seu tempo a plenitude do ideal da vita activa: a possibilidade de participação plena na vida política de sua comunidade. Político prático e diplomata experiente, só começou a redigir a parte mais importante de sua reflexão quando, com o retorno dos Médicis, se destruiu a República livre à qual havia servido por mais de uma década. Por essas circunstâncias, Maquiavel não pode mesmo ser classificado como um teórico político de academia. ${ }^{14}$

Segundo a análise do historiador alemão Raymond Gettel, Maquiavel exerceu influência marcante na vida política de seu tempo. Segundo Gettel, as suas argutas avaliações acerca do governo de Florença bem como dos demais reinos da Europa, onde esteve presente como observador direto em certas embaixadas diplomáticas, acabam por se refletir na metodologia e na peculiar natureza da sua filosofia política. ${ }^{15}$ Sua biografia é uma história entrecortada por frustrações e insucessos, explicáveis pelas circunstâncias históricas pelas quais passou Florença na confluência dos séculos XV e XVI. Como afirmam alguns de seus comentadores, há muitos níveis de intenção em $O$ Príncipe que ultrapassam o "oportunismo raso e vulgar do qual ele é frequentemente acusado. (...) o oportunismo terra-a-terra, por assim dizer 'alimentar'". ${ }^{16}$ Desse modo, ele considerou o seu próprio ostracismo como um tempo de privações provisórias como, aliás, bem o demonstram algumas das mais famosas peças de seu epistolário: as cartas ao embaixador de Florença em Roma, Francesco Vettori. ${ }^{17}$ Contudo, seu cri de coeur foi revelado ao amigo Guicciardini numa carta de 16 de abril de 1527, ano de sua morte: "Amo a minha pátria mais que a minha alma". ${ }^{18}$

A sucessão dos regimes políticos dos anos 1494 a 1527, período das experiências políticas mais intensas e da trajetória intelectual de Maquiavel, marca uma fase conturbada na história de Florença. Essa foi a época das Guerras da Itália, em que as repúblicas e os principados — pequenas e frágeis unidades políticas se tornaram presas fáceis para os grandes Estados monárquicos emergentes na Europa ocidental, notadamente a Espanha e a França. O secretário da República

${ }^{14}$ Acerca da vida pública do secretário da Segunda Chancelaria de Florença leia-se LARIVAILLE, Paul. «O caso Maquiavel ou o intelectual frente ao poder». In: —_. A Itália no tempo de Maquiavel. São Paulo: Companhia das Letras, 1988. p. 143ss.

${ }^{15}$ Cf. GeTtELl, Raymond. Op. cit., p. 164s.

${ }^{16}$ LARIVAille, Paul. Op. cit., p. 146.

${ }^{17}$ Cf. Maquiavel, Nicolau. Epistolário. México: FCE, 1993.

18 Citado em Wolin, Sheldon. Política y perspectiva. Continuidad y cambio em el pensamiento político occidental. Buenos Aires: Amorrortu Editores, 1973. p. 223. 
florentina fez o seu aprendizado numa época de sobressaltos na geografia política europeia. A constituição de Florença mudou seis vezes no transcurso de apenas quarenta anos. Desde 1494, a Itália havia se convertido em campo de batalha dos exércitos europeus. Até 1495 Florença foi um principado, nesta altura sob a liderança de Lorenzo, o Magnífico, título conferido ao príncipe Médici por ter sido o maior estimulador das artes de seu tempo. De 1495 a 1498, a cidade tornou-se uma espécie de monarquia teocrática, sob a liderança efêmera de Savonarola, o "profeta desarmado", segundo o definiu Maquiavel, exemplo de idealismo e fracasso.

Os anos de 1498 a 1512 marcam o período da instauração da República, época de ouro para Maquiavel. A república foi derrubada pelos espanhóis. Com a restauração dos Médici (1512 a 1527), Maquiavel foi preso e, inclusive, torturado, sob a acusação de ter participado de um complô contra o novo regime. Nove anos depois seria nomeado historiador oficial de Florença. ${ }^{19}$ Com a restauração da República, ocorrida em 1527, caiu no ostracismo novamente. Morreu no mesmo ano, infeliz por ter sido identificado, pelos republicanos, com o regime dos tiranos. De fato, constatado o colapso do regime republicano, seu realismo político levou-o a crer que os Médicis pudessem encarnar o espírito de uma liderança italiana. ${ }^{20}$ Mas esse ciclo de revoltas e golpes de Estado fez Florença - até então a "escola da Renascença" - decair para uma posição caudatária em relação a Roma e a Veneza.

Tais dados extra textuais certamente ajudam a situar o personagem. Mas, como em todo texto clássico, em sua obra também há conceitos centrais da política que não podem passar despercebidos. Sem dúvida, a abordagem diacrônica que o historiador Maquiavel dá à narrativa de processos políticos, com os seus exempla extraídos da história de vida de personagens ilustres é um aspecto central em seus textos. Nos Discursos, ele faz a seguinte profissão de fé em seu método de historiador:

19 Acerca de Maquiavel como historiador ver as seguintes análises: BignOTTO, Newton. «Natureza humana e história». In: —_. Maquiavel republicano. São Paulo: Loyola, 1991; RIDOLFI, Roberto. «Nicolau Maquiavel, historiador». In: —_. Biografia de Nicolau Maquiavel. São Paulo: Musa Editora, 2003; e SKINNER, Quentin. «O historiador de Florença». In: —. Maquiavel. Porto Alegre: L\&PM, 2010. Para uma abordagem mais generalizante sobre a história política no tempo de Maquiavel, com Maquiavel incluído, ver FUETER, Eduard. «La nueva historiografía política de Florencia a comienzos del siglo XVI». In: ——. Historia de la historiografía moderna. Buenos Aires: Editorial Nova, 1953. Vol. 02; e Collingwood, Robin George. «Os historiadores do Renascimento».

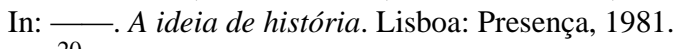

${ }^{20}$ Cf. MAYER, J.P. Trayectoria del pensamiento político. México: FCE, 1985. p. 89. 
"Resolvido a salvar os homens deste erro, achei necessário redigir, a propósito de cada um dos livros de Tito Lívio que resistiram à injúria do tempo, uma comparação entre fatos antigos e contemporâneos, de modo a facilitar-lhes a compreensão. Deste modo, meus leitores poderão tirar daqueles livros toda a utilidade que se deve buscar no estudo histórico". 21

Tanto assim que "A leitura da história", afirma De Grazia, "não deve ser por prazer nem mesmo por admiração. O objetivo deveria ser a utilidade". ${ }^{22}$

Inegavelmente, a lógica de Maquiavel gira sobre dois eixos, ou melhor, sobre dois princípios conceituais, inspirados numa perspectiva eminentemente histórica da política: virtù e fortuna. Virtù não é mera imagem retórica da ideia de mutabilidade das coisas, mas motor das alterações, a força de arrancada do príncipe, o ímpeto, a vontade, a capacidade do indivíduo de, confrontando-se com consideráveis obstáculos, sobrepor-se a eles, abrindo caminho mesmo contra as maiores adversidades. A síntese de virtù é, sem dúvida, o heroísmo e a "capacidade de explosão" dos grandes personagens históricos ou lendários, desde que os seus exemplos fossem dignos de serem imitados. Trata-se de um conceito tomado de empréstimo à Antiguidade e ao humanismo de seu tempo, mas remodelado por Maquiavel.

A virtù implica ações muito afirmativas, algo assim como as atitudes do cirurgião, que amputa membros e cauteriza feridas e tudo o mais que for requerido por seu ofício, sem poder demonstrar fraqueza ou hesitação diante das dores e dos infortúnios que causará com suas atitudes. E isso porque, nas práticas médicas, há um tempo certo para a execução das ações requeridas por circunstâncias muito passageiras, ações que definem a vida e a morte. No processo político não é muito diferente em relação ao que se espera das atitudes do príncipe. De modo algum se fala de boa conduta. Trata-se de uma força criadora em estado de permanente tensão. $\mathrm{O}$ conceito ou a ideia remontam a tempos distantes, mais particularmente à Roma antiga. Para Maquiavel a virtù “... está muito mais próxima do termo latino virtus ou 'hombridade e excelência', ou à ideia grega de arete, que pode ser traduzida como a "excelência específica de uma coisa". ${ }^{23}$ A política e o Estado, sob o império da virtù, em meio a um contexto de corrupção no qual tudo é fugaz,

${ }^{21}$ Maquiavel, Nicolau. Comentários sobre a Primeira Década de Tito Lívio. Op. cit., p. 18.

22 De GraZIA, Sebastian. «O espelho do príncipe novo». In: - Maquiavel no inferno. São Paulo: Companhia das Letras, 2000. p. 298.

${ }^{23}$ Chrisholm, Robert. «A ética feroz de Maquiavel». In: QuiRIno, Célia. et alii. (Org.). Op. cit., p. 59. 
transformam-se em pura "obra de arte do príncipe" 24 (Burckhardt), uma matéria plástica, algo moldável quando sob a ação de um hábil construtor. A virtù é a arte de andar sempre em conformidade com as circunstâncias, pode-se afirmar. E isso porque ela pode ou deve ser, a um só tempo, engenho e força bruta, em ações bem articuladas.

A virtù em Maquiavel substitui a visão providencialista da história, porque define o controle do curso dos acontecimentos como algo pertinente à alçada da inspiração e do cálculo humanos, e não mais como valor submetido à tutela exclusiva de desígnios insondáveis, de uma vontade transcendente e desconhecida. O conceito de virtù advém, em boa medida, da visão do historiador. Para ele, o curso da história poderá recair sob o império do príncipe que, estudando atentamente os acontecimentos do passado, conseguirá guiar e/ou desviar, conforme o caso, o sentido dos acontecimentos em seu próprio favor. Este controle do curso da história é possível, acreditou Maquiavel, porque a natureza humana é sempre a mesma, em todos os tempos. Assim é que, qualquer embaraço que possa acarretar a ineficiência das ações do príncipe, é condenada por ele. ${ }^{25}$

Fortuna é um conceito complementar à virtù, e que também ajuda a explicar a dinâmica da história maquiaveliana. A fortuna rege parte significativa da ação política dos homens de Estado e simboliza "os fatores incontroláveis" ${ }^{26}$ Como afirma Maquiavel, onde e quando os homens revelam fraqueza, abre-se campo para que a fortuna demonstre as suas virtudes. É fácil ver que a obra de Maquiavel está cheia de metáforas alusivas ao mundo natural. ${ }^{27}$ Assim é que a fortuna foi representada por ele na forma de um rio caudaloso, cuja força destruidora pode ser controlada por meio da previdência humana, pelos ardis antecipados, pela aplicação de golpes precisos e eficazes de astúcia e calculismo contra as forças contrárias aos interesses de uma comunidade política. E o príncipe encena o papel de estrategista, ele é um ator político versado "no domínio da arte das ilusões", segundo a expressão de Sheldon Wolin. A fortuna também é simbolizada por uma mulher, que deseja ser conquistada pelo herói, mas que impõe certa resistência, determinadas condições para ceder aos apelos, numa estratégia típica do jogo de

\footnotetext{
${ }^{24}$ Naturalmente, no caso de Maquiavel não se trata de uma meta artística, estética, que é o sentido atribuído por Burckhardt. A esse respeito consulte-se Wolin, Sheldon. Op. cit., p. 237.

${ }^{25} C f$. Isaiah BERLIN. «La originalidad de Maquiavelo». In: —_. Op. cit., p. 108.

${ }^{26}$ Wolin, Sheldon. Op. cit., p. 228.

27 Acerca do sentido de metáforas naturais na obra de Maquiavel e suas analogias com a sociedade política consulte-se Wolin, Sheldon. Op. cit., p. 218; e GRANADA, Miguel. Cosmologia, religión y política en el Renacimiento. Barcelona: Anthropus, 1988.
} 
sedução. Maquiavel se utiliza também de metáforas zoológicas para caracterizar as virtudes do príncipe modelar em meio a seus combates pela conquista e pelo equilíbrio do Estado. Assim, o príncipe deve ser forte como o leão, astuto como a raposa, para não ser devorado pelos lobos.

Para Maquiavel, a virtù carregava a mesma carga semântica que possuíra entre os antigos romanos. $\mathrm{Na}$ sua acepção mais ampla, queria dizer virilidade, força. Contudo, há uma mensagem subliminar que parece afirmar: além de possuir energia militar, ao príncipe cabe ser sagaz, prudente e previdente. Se há um embaraço que se apresente como um percalço acima de seus recursos numa dada conjuntura, ele deve retroceder, aguardando o advento de circunstâncias mais favoráveis para a ação. Entretanto, esperar demasiadamente, deixando passar o momento fugaz da oportunidade, que dá a senha para a realização do feito da conquista, é incorrer em grave equívoco. Maquiavel foi favorável ao poder de decisão como atributo do governante. Portanto, ele desprezou qualquer política vacilante, sobretudo aquela que representasse risco para a segurança do Estado.

Com sua nova visão da política, convertendo-a numa categoria à parte de princípios morais, Maquiavel desferiu alguns golpes bem rudes no ideal da realeza cristocêntrica e hereditária, legado transmitido pelas tradições da Idade Média à cultura da Época Moderna. Contudo, ele não conseguiu esvaziá-la de seu conteúdo teológico-religioso. A prova disso está no fato de a teoria do direito divino dos reis ter se desenvolvido e se consolidado como base doutrinal de Estados monárquicos europeus - particularmente a Inglaterra dos Stuarts e a França dos Bourbons muito tempo depois dele ter escrito seus livros. Mas, é sabido que o autor não negou o valor dos princípios éticos. Apenas os dissociou da política, liberando o príncipe para executar algumas manobras que seriam inconcebíveis se ele tivesse de se pautar por qualquer espécie de freio moral. Ao declarar o príncipe livre de toda restrição legal e moral, apregoando um novo catecismo de realismo político, Maquiavel somente podia argumentar que a força era a essência da justificação do poder. Isso é como afirmar que ao príncipe é lícito tudo aquilo que não o é ao homem comum. Assim sendo,

"Maquiavel argumenta que a moralidade cristã, por mais útil que seja como instrumento de disciplina para um único indivíduo em termos privados, é simplesmente incompatível com a política como atividade prática. (...) Por isso, as virtudes cristãs são inteiramente inadequadas para qualquer um que se devote à vida política, seja ele príncipe ou cidadão". ${ }^{28}$

\footnotetext{
${ }^{28}$ Chrisholm, Robert. «A ética feroz de Maquiavel». In: Quirino, Célia. et alii. (Org.). Op. cit., p. 57.
} 
Tal argumento pode significar que, em Maquiavel, há dois mundos, o da moralidade pessoal e o da organização pública. Há igualmente dois códigos éticos, ambos fundamentais na vida em comum. ${ }^{29}$ Essas manobras radicais empreendidas por Maquiavel no campo do pensamento político representaram uma ousada fluidificação de conceitos, um embaralhamento inovador das chamadas virtudes cardeais que regiam a ação ou o comportamento dos príncipes. Como ele afirmou, numa passagem dos Discursos, o mal está tão entrelaçado ao bem que frequentemente se chega a um achando que se atingiu ao outro. Desse modo, Maquiavel diversifica o quadro das ditas virtudes dos espelhos de príncipes: o que era um vício deplorável do príncipe cristão pode não sê-lo mais, e até pelo contrário, segundo a bitola anticlerical de Maquiavel. Esse maquiavelismo parece ter feito eco em outras gerações e culturas. La Bruyère, por exemplo, na segunda metade do século XVII, considerava que "não há vício que não tenha alguma semelhança com qualquer virtude e que dela não se aproveite". ${ }^{30} \mathrm{O}$ mesmo foi afirmado nas máximas de La Rochefoucauld, ${ }^{31}$ no testamento político de Richeleieu, ${ }^{32}$ nas reflexões de Mazarino ${ }^{33}$, nas memórias de Luís XIV $^{34}$ e, com rigor superlativo e em tom de crítica desabonadora, nos textos políticos de Hobbes. $^{35}$

Analisando $O$ Príncipe, Quentin Skinner explica as referidas fluidificações promovidas no terreno das palavras, o que permitiu expressar novas acepções conceituais e vinculá-las a novos conteúdos da ação política, que as realidades emergentes passaram a requerer. Com efeito, certas acomodações minimizadoras dos sentidos de algumas palavras-chave do vocabulário normativo encontradas em $O$ Príncipe enquadravam-se nas técnicas retóricas formuladas por autores romanos, como Cícero e Quintiliano. O método das soluções acomodatícias de sentidos consistia em operar o discurso por meio de "redescrições morais" (também definidas como "redescrições paradiastólicas"), o que significava que a arte do escritor político poderia consistir em "adoçar" as palavras, abrandamento que as tornaria agradáveis aos observadores das ações dos governantes quando observadas por um ângulo um pouco mais favorável do que aquele tido como o mais

${ }^{29}$ Cf. BERLIN, Isaiah. «La originalidad de Maquiavelo». In: —. Op. cit., p. 120.

${ }^{30}$ LA BRUYÈre, Jean de. Les caractères ou les moeurs de ce siècle. Paris: Hachette, 1890. p. 119.

${ }^{31}$ Cf. La Rochefoucauld. Máximas e reflexões. Rio de Janeiro: Imago, 1994.

32 Cf. Richelieu. «Testament politique». In: GauCHERON, Roger. (Org.). Oeuvres du Cardinal de Richelieu. Paris: Plon, 1933.

${ }^{33}$ Cf. MAZARINo. Breviário dos políticos. Brasília: Alhambra, s/d.

${ }^{34}$ Cf. LouIs XIV. Mémoires. Paris: LCL, 1960.

${ }^{35}$ Cf. HobBes, Thomas. Do cidadão. São Paulo: Martins Fontes, 2002. 
tradicional. Assim sendo, como ponto culminante do processo discursivo, a técnica da redescrição paradiastólica investia na sempre arriscada tarefa de tornar honroso e louvável o que, à primeira vista, não passava de algo deplorável e vil, conforme consagração prévia dos costumes e do senso comum. Com o fito de atrair a opinião pública favoravelmente a uma determinada causa julgada de antemão de difícil defesa, a ideia era maquinar certos truques de esperteza na modelagem dos sentidos das palavras, numa atitude de provocar deliberada confusão entre as noções de bem e de mal, para demonstrar com clareza solar que algumas ações aparentemente malévolas poderiam carregar escondido algo muito positivo; tais ações, antes vistas como vícios, devidamente "amaciadas" pela ars rhetorica, revelar-se-iam altamente compensatórias, mormente quando o bem público estivesse em jogo. E havia a crença dominante de que um orador excelente não poderia ser coisa distinta de um não menos excelente cidadão. Assim sendo, as excelências de sua arte retórica seriam sempre instrumentalizadas para a promoção do bem viver. Desse modo, nenhum problema com a profusão de metáforas bem arranjadas, nem com a presença de outras figuras de linguagem, todas elas voltadas para ornamentar uma intervenção discursiva. Afinal, do orador se esperava a produção de cenas eloqentes na imaginação de sua assistência, como se ela própria estivesse diante do quadro apresentado. Como disse Quintiliano acerca da capacidade verbal de Cícero, ao bom orador cabe "pintar com palavras". 36

Resta que o apoio de autoridades de tão grosso calibre como Cícero e Quintiliano contribuiu para erguer uma onda de oposição e repressão originária das redescrições morais feitas por Maquiavel haja vista que, ao longo da Época Moderna, a perspectiva de que a retórica nem sempre estaria ao lado da realização do bem público evidenciou-se vivamente. $\mathrm{O}$ movimento crítico às ditas redescrições fez-se sentir de imediato, e não foram poucas as reações renascentistas contrárias à arte de tingir o discurso, por meio de variada coloração (ornatus) o vício, de virtude. A literatura política do século XVI está repleta de exemplos de pensadores que abominaram a utilização dos atavios de linguagem para minimizar os defeitos do vício no campo semântico, atribuindo-lhe uma aparência agradável no terreno das ações. A lição central a ser extraída das críticas restritivas ao discurso paradiastólico era da seguinte ordem: não se deve utilizar ramos perfumados para encobrir a fragrância que exala de valores morais decompostos e qualquer defesa realizada neste sentido é imoral e, portanto, inaceitável. Como nos inícios da Época Moderna o campo das controvérsias políticas povoara-se de

36 Acerca das regras da eloqência dos autores antigos e sua recepção pela cultura do Renascimento ver SKINNER, Quentin. Razão e retórica na filosofia de Hobbes. São Paulo: Editora Unesp, 1999. 
interlocutores de distintas tendências, havia a possibilidade de se ouvir objeções moralizantes dirigidas tanto por católicos como protestantes, em suas distintas linhagens. Ora, até mesmo para os entusiastas das redescrições morais, a técnica de tonificar um salmão já sob o inegável impacto da ação corrosiva do tempo, descarregando especiarias, decerto que era mesmo algo percebido como dura tarefa. Mas nem por isso impossível de ser levada a cabo com êxito para alguns retóricos mais virtuosos. Desse modo, as então consideradas "virtudes fingidas", bem como os conhecidos "enganos proveitosos", encontraram abrigo confortável nos textos de um conjunto respeitável de escritores políticos do Renascimento e mesmo ao longo do século XVII. ${ }^{37}$

Contrariamente a Hobbes, cuja pretensão no plano da retórica política foi a de estabelecer tanto quanto possível uma univocidade dos conceitos, Maquiavel trafegou livremente no terreno das redescrições morais. E o que resta como ponto pacífico do realismo maquiaveliano é que o estabelecimento do critério justo ou adequado dependerá do grau de eficácia alcançado pelo soberano em suas investidas. A crueldade, por exemplo - vício abominável quando julgado pelo prisma da tradição política cristã - pode tornar-se uma elevada virtude, se for empregada segundo o oportuno princípio da "economia da violência", uma ciência da aplicação controlada e eficaz da força. Tal lógica, quando aplicada, assemelhase a um tratamento de choque, breve mas severo, destinado a restaurar a unidade do Estado. ${ }^{38}$ Nesse nível, ele recomenda atitudes que se assemelhem à velha e boa política romana, o que significa que adversários que representem riscos merecem atenção especial, "...de maneira que nunca, em tempo algum, pudessem incomodar". ${ }^{39}$ Esse é um texto burocrático de embaixada, datado de 1502, o que parece revelar que, no plano das fontes do realismo político maquiaveliano, algumas noções centrais já estavam consolidadas muito tempo antes de o autor se dedicar à composição de seus grandes textos políticos. ${ }^{40}$ No plano das táticas de um terror sangrento, ou da lógica da economia da violência, Maquiavel tencionou

${ }^{37}$ Cf. SKINNER, Quentin. As fundações do pensamento político moderno. São Paulo: Companhia das Letras, 1996. p. 269.

${ }^{38}$ Cf. Wolin, Sheldon. Op. cit., p. 239.

39 MAQuiavel, Nicolau. «Do modo de tratar os povos rebelados do vale do Chiana». In: —. Escritos Políticos. São Paulo: Abril Cultural, 1973. p. 130. (Coleção Os pensadores).

40 É o que se pode apreender também acerca de sua noção da política como "categoria autônoma", a partir da leitura de outra de suas composições de embaixada, na qual narra os passos do belissimo inganno - expressão que poderíamos atualizar como "chacina de Sinigaglia" composição igualmente redigida em 1502. Cf. MAQuiAVEL, Nicolau. «Descrição do modo de que se serviu o Duque Valentino para matar Vitellozzo Vitelli, Oliverotto da Fermo e o Duque de Gravina Orsini». In: —. Escritos Políticos. Op. cit., p.149ss. 
argumentar que, em muitos casos, a clemência só faz aumentar o atrevimento do inimigo. Assim sendo, é dado ao governante mostrar-se tolerante ou magnânimo apenas se destas virtudes não derivar ensejo para a desordem. Mas, é preciso estabelecer as devidas nuanças desses preceitos. Como bem observa Robert Chrisholm, “... isso não quer dizer que Maquiavel acredita que o fim justifica os meios". ${ }^{41} \mathrm{Na}$ mesma direção aponta Kenneth Rexroth, para quem Maquiavel tampouco acreditou que os fins justificavam os meios. ${ }^{42}$

Assim sendo, seria necessário, e mesmo imprescindível, que o efeito gerado por uma ação cruel ou até bestial fosse favorável a uma determinada intenção. Se o resultado fosse bom, não haveria escrúpulos quanto a mãos sujas de sangue. Isso é o mesmo que afirmar, com Raymond Aron - em suas análises críticas acerca do silêncio ou da complacência dos intelectuais de esquerda diante dos crimes do stalinismo - , que o fim sublime justifica os meios odientos. ${ }^{43}$ Então, o que é a crueldade, segundo o "alisamento"moral de Maquiavel? Pode ser o emprego calculado dos ditos expedientes extraordinários como fonte de inspiração à fidelidade a uma bandeira desfraldada pelo soberano. Mas, desde que seus desdobramentos fossem duradouros. Isso porque não seria um sucesso simples que justificaria a utilização dos meios extraordinários. Um sucesso efêmero seria pouco mais que nada. Mas uma herança permanente mudaria tudo de figura. ${ }^{44}$

Inegavelmente, $O$ Príncipe foi obra de circunstância para incensar e sensibilizar os poderosos do tempo em prol de uma causa particular. Para uma obra que foi escrita, dentre outras motivações, como uma luta desesperada para reaver um emprego e/ou uma posição social, o autor jamais poderia prever a fortuna crítica que seu livro obteria. Mas essa foi a história de um sucesso feito principalmente de desventuras, com reações que variam da indiferença calculada à admiração mais entusiástica como, por exemplo, a demonstrada na distante posteridade por Napoleão e Mussolini. Não tardou muito para que o livro fosse incluído no sumário das obras proibidas pela Igreja. Nos anos imediatos à sua primeira divulgação, a obra não teve repercussão. Afirma-se que Lorenzo de Médici, a quem o livro foi oferecido ao estilo Pro domo sua, sequer o abriu. Limitou-se a uma resposta cortês 53.

${ }^{41}$ Chrisholm, Robert.«A ética feroz de Maquiavel». In: Quirino, Célia. et alii. (Org.). Op. cit., p.

42 "Considero em detalle qué médios deben emplearse para crear qué fins: concepto en extremo diferente”. ReXroth, Kenneth. Recordando a los clásicos. México: Fondo de Cultura Económica, 1993. p. 153.

${ }^{43}$ Cf. Aron, Raymond. L'opium des intellectuels. Paris: Gallimard, 1968. p. 222. p. 69.

${ }^{44}$ Chrisholm, Robert. «A ética feroz de Maquiavel». In: Quirino, Célia. et alii. (Org.). Op. cit., 
de agradecimento, acompanhada por duas garrafas de vinho, que fez remeter ao autor.

Segundo Quentin Skinner, durante algum tempo a república europeia das letras fez um estrondoso silêncio em torno desse livro. Mas houve também um tempo em que os detratores do realismo maquiaveliano saíram abertamente a campo no intuito de decaptar a hidra, ${ }^{45}$ tal a ferocidade da resistência. Como adverte Elena Cantarino em seu artigo acerca da tradição espanhola quinhentista e seiscentista reativa aos princípios lançados pelo historiador de Florença, ao terçar armas com ele seus adversários fizeram um belo trabalho em torno de sua divulgação involuntária. Ao mover contra suas ideias um intenso combate moral, o resultado talvez imprevisto mas certamente indesejado foi a amplificação do espectro de suas concepções. ${ }^{46}$ De todo modo a indiferença de Maquiavel pela verdade ou pela falsidade da religião acabou por ser uma característica comum do pensamento moderno, mas não foi uma referência marcante do pensamento nos séculos XVI e XVII. Durante vários séculos, a Cristandade continuaria pensando não nos termos da política secular, como ele a concebia, mas teologicamente. Desse modo, considerou blasfema a filosofia que Maquiavel desenvolveu. A crueza de seu realismo político assustou a seus contemporâneos e aos pósteros, e, até hoje, a política de Maquiavel arrepia as mentes mais recatadas, quando se reflete na dureza de sua execução e na crueza de suas consequências. Isso porque sempre fica no ar certo "satanismo sinistro", segundo a expressão de Isaiah Berlin, presente na seguinte interrogação: ao príncipe tudo é permitido para a realização de seus projetos? Se não for possível viabilizá-lo por meios normais a resposta é afirmativa. $^{47} \mathrm{~A}$ necessidade não conhece leis, eis a máxima que expressa cristalinamente o imperativo categórico maquiaveliano.

As reações de perplexidade em relação a $O$ Príncipe se devem ao fato de o realismo maquiaveliano ultrapassar os horizontes das possibilidades lógicas e morais do homem médio de seu tempo. Ora, no século XVI seria inconcebível

\footnotetext{
45 Emblemática de tal resistência ao maquiavelismo é a obra de 1628, de autoria do escritor da "escola idealista" do pensamento politico Claudio Clemente, obra justamente intitulada El Machiavelismo Degollado, por la Christiana Sabiduria de España y de Austria: Discuro ChristianoPolítico a la Catholica Magestad de Philippo, Rey de las Españas. Citada por CANTARINo, Elena. «Tratadistas político-morales de los siglos XVI y XVII: apuntes sobre el estado actual de la investigación». El Basilisco. Revista de Filosofía, Ciencias Humanas, Teoria de la Ciencia y de la Cultura. Oviedo, 21, 1996. p. 4-7.

${ }^{46}$ CANTARINO, Elena. «Tratadistas político-morales de los siglos XVI y XVII: apuntes sobre el estado actual de la investigación». Op. cit.

${ }^{47}$ Cf. SKINNER, Quentin. As fundações do pensamento político moderno. Op. cit.,
} 
raciocinar que a religião não era uma das esferas de realidade profundamente enraizadas no poder político, e que o contrário também era verdadeiro. Ao isolá-la como ferramenta de manejo das massas, Maquiavel fez a religião "descolar" de seu chão histórico. Para Sheldon Wolin, esta operação intelectual só foi possível a Maquiavel por sua condição de personagem histórico vivendo em um contexto muito peculiar: a cidade-Estado do Renascimento italiano. Circunstâncias semelhantes existiram somente na Itália durante o século XVI. Por essa época, os intelectuais empregavam cada vez mais suas energias na exploração de novos objetos de reflexão, sem que se deixassem distrair por intermináveis polêmicas religiosas. ${ }^{48}$ Interpretação convergente é a desenvolvida por George Sabine, para quem esses intelectuais, se tivessem escrito em outra região que não fosse a Itália, ou se tivessem escrito na própria Itália depois do início da Reforma e, ainda mais, depois do início da Contra-Reforma na Igreja, é impossível supor que houvessem tratado a religião da maneira que fizeram. ${ }^{49}$

Em seus conceitos políticos Maquiavel "pecou" tanto por excesso que acabou por fazer o humanismo entrar em rota de colisão com a visão religiosa predominante em sua época. Ao renegar o providencialismo, o Deus ex machina na história, ele desencadeou um debate secular entre sua obra e as várias tradições do pensamento político europeu na segunda metade do século XVII. Bossuet foi um de seus críticos, a propósito do príncipe por direito hereditário, renegando com fervor ultracatólico o princípio da virtù. Para Maquiavel, a virtù era uma espécie de "ginástica da vontade", que só algumas criaturas excepcionais desenvolviam no grau necessário para credenciar-lhes o trânsito nas altas esferas da vida pública.

Em outras regiões da Europa, mais precisamente nos grandes Estados territoriais emergentes, que eram os modelos visados por Maquiavel para servir de exemplo à situação italiana, $O$ Príncipe soava como um livro escrito em um idioma sem tradução. A Europa cristã na Idade Moderna teve uma atitude de surdez seletiva diante do texto. Então, esses seriam indicadores de que Maquiavel teria feito a obra do pregador no deserto? Nem tanto assim. A lógica contingente do maquiavelismo político criou efeitos paradoxais. Príncipes eclesiásticos, que por razões de ofício combateram as ideias de Maquiavel, no corpo-a-corpo da política fizeram largo emprego de seus métodos. A raison d'Etat, na forma como é expressa no Testament Politique de Richelieu, parece demonstrar que a universalidade atribuída ao maquiavelismo político é um engano. Entre os valores

${ }^{48}$ Cf. Wolin, Sheldon. Op. cit., p. 212.

${ }^{49}$ Cf. SABINE, George. História das Teorias Políticas. Rio de Janeiro: Editora Fundo de Cultura, 1964. (Vol. 01). p. 280. 
morais do príncipe em voga no fim da primeira metade do século XVII, o Testament Politique acentua a severidade que o soberano deve observar em sua conduta: “... é preciso, por necessidade, que um príncipe seja severo", considera o Cardeal. $^{50}$ Parafraseando uma expressão de Leo Strauss, a política efetiva de Richelieu era, a exemplo daquela teorizada por Maquiavel, uma "política a ferro e sangue". A purificação do corpo político pela "chama sagrada da violência" (Sheldon Wolin) foi representada pelo triunfo de Richelieu sobre os huguenotes, em La Rochelle.

As Guerras de Religião, que após o advento da Reforma, fizeram correr rios de sangue entre facções políticas adversárias e inconciliáveis em profissão de fé, criaram condições pouco favoráveis à secularização das ideias políticas. A Reforma protestante teve como resultado mesclar ainda mais a política efetiva e o pensamento político com a religião, e de uma forma muito mais ostensiva do que ocorrera durante a maior parte da Idade Média. Exemplo disso é a célebre Vindiciae contra tyrannos e a sua teoria justificadora do tiranicídio, um atentado contra o corpo sagrado do rei, segundo as crenças predominantes à época. Como os católicos, em seu empenho na defesa do direito divino dos reis, os protestantes também buscavam as suas justificativas nas Sagradas Escrituras. A Bíblia foi transformada num gládio cortante.

Mas, acerca de Maquiavel, os historiadores Ruggiero Romano e Alberto Tenenti refletem que "sua obra desmistificadora acabou se tornando, de uma maneira direta e por vezes não confessada, em algo libertador para a reflexão política posterior". ${ }^{51}$ Na obra $O$ mito do Estado, Ernst Cassirer afirma que vários argumentos de Maquiavel estavam destinados a ser, no século XVIII “... o grão que alimentava os moinhos dos filósofos franceses". Depois de ter considerado a recepção hostil que o pensamento de Maquiavel recebeu no Século XVII, o filósofo teuto-americano adverte que "Os pensadores do século XVIII, os filósofos do Iluminismo, viram o caráter de Maquiavel a uma luz mais favorável. Num certo sentido, Maquiavel parecia ser o seu aliado natural. Quando Voltaire desfechou o seu ataque contra a Igreja Católica, quando pronunciou o seu famoso Écrasez l'Infâme, podia considerar-se a si próprio um continuador de Maquiavel". ${ }^{52}$

${ }^{50}$ RichelieU. «Testament politique». In: GAUCHERON, Roger. (Org.). Op. cit., p. 153.

${ }^{51}$ Romano, Ruggiero. \& Tenenti, Alberto. Los fundamentos del mundo moderno. Madrid: Siglo XXI, 1972. p. 156.

${ }^{52}$ CASSIRER, Ernst. O mito do Estado. São Paulo: Códex, 2003. p. 156. 
Para Rousseau, por exemplo, leitor atento de Maquiavel no século XVIII, o retrato repugnante do tirano foi concebido pelo autor com o nobre propósito de instruir o povo contra a tirania. ${ }^{53}$ Para sacar a conclusão de que Maquiavel havia escrito contra os poderosos, Rousseau cotejou O Príncipe com os Discursos, livro no qual o "preceptor" e fiel "escudeiro" de príncipes é republicano até a medula. Mas há quem lembre, com razão, que ele preferia um principado bem governado a uma república decadente.

Em O Príncipe, e também nos Discursos, são profusas as cenas protagonizadas por personagens da mais elevada estatura, todos dotados de altaneiras virtudes para preencher o primeiro posto de um Estado. Com efeito, na passarela maquiaveliana são colocadas em movimento figuras antigas e modernas, da estirpe de um Moisés, de um Dario, de um Cipião e demais príncipes seculares e eclesiásticos de seu tempo. Na inspirada nota de Sebastian de Grazia, em seus livros, Maquiavel passa o tempo "recrutando e instruindo os pretendentes". Castruccio Castracani parece ter sido concebido por Maquiavel como uma dessas criaturas modelares. Recolhido na "roda dos enjeitados", acabou por se tornar a figura proeminente para o seu espelho de príncipe intitulado, precisamente, Vida de Castruccio Castracani. ${ }^{54}$

Como se afirmou, Maquiavel foi o proponente da política como "categoria autônoma", desembaraçada de qualquer pressuposto moral ou teológico-religioso. A religião passou a ser reconhecida por ele como instrumento ideológico útil, permitindo ao soberano empregá-la como ferramenta de estímulo das virtudes cívicas. Para ele, a religião seria um sustentáculo ideológico do poder, quando utilizada de forma hábil pelos governantes, porque canalizaria as energias primitivas mais vigorosas do povo, para a defesa da estabilidade e da ordem política. É nesse sentido que se pode falar, com razão, de uma concepção sociológica e de um emprego instrumental da religião admiravelmente modernos na obra do historiador florentino.

${ }^{53}$ De fato, a categoria povo é essencial em Maquiavel. Essa importância, certamente, está ligada a uma percepção moderna da política, em que se mesclam o ideal republicano e a pragmática do poder. Mas, na análise de Kenneth Minogue acerca da política no Iluminismo, os súditos “... eram agora letrados e tinham opiniões políticas e religiosas próprias, bem definidas, que poderiam levá-los a apoiar uma mudança de regime”. Minogue, Kenneth. Política: uma brevíssima introdução. Rio de Janeiro: Jorge Zahar, 1998. p. 51.

${ }^{54}$ Cf. MAQUIAVEL, Nicolau. A arte da guerra e outros ensaios. Brasília: Editora UnB, 1982. Uma excelente definição do gênero de literatura política espelhos de príncipes, e a vinculação de Maquiavel a ele, encontra-se sintetizada em DE GRAZIA, Sebastian. «O espelho do príncipe novo». In: - Op. cit., p. 291. 
Assim procedendo, ele abalou a base da teoria política à moda dos espelhos de príncipes da tradição cristã medieva, e é dessa forma que o seu título de fundador da ciência política moderna é perfeitamente justo e legítimo. A longuíssima obra de desconstrução da teologia e do providencialismo na tradição política encontrou nele o seu arquiteto mais inventivo, promotor entusiástico de revelações ímpias assestadas contra o ingênuo governo dos santos. Ernst Cassirer o considera como uma espécie de climax da dessacralização milenar da cultura no Ocidente. Entretanto, Isaiah Berlin não reconheceu o estabelecimento da política como "categoria autônoma" por parte de Maquiavel. Este autor preferia ver aí um conflito da moral romana com a cristã, em que esta última não encontrou espaço na teoria da ação política de Maquiavel. Sem dúvida, os Comentários sobre a Primeira Década de Tito Lívio permitem essa interpretação. Os valores de Maquiavel não são cristãos, mas são valores morais. Como a de Aristóteles ou a de Cícero, a moralidade de Maquiavel era social, não individual. Mas é uma moralidade, não menos que a de Aristóteles e a de Cícero. No pensamento de Maquiavel não há uma região amoral, mas há dimensões que vão além do bem e do mal. $^{55}$

Assim sendo, a originalidade de Maquiavel não está propriamente na dessacralização da política, mas na separação de vida pública e privada (secularização da política), nas ditas escolhas dolorosas que o poder impõe, nos ditos "meios extraordinários" de que é preciso lançar mão, que ele mesmo define por "armas e violência". Esse é bem o caso de Brutus: a consciência do dever levao à execução de seu filho, que traíra a República romana. É o caso também, ainda no plano das ações mais radicais, do lendário fundador de Roma. Alguém pode ser denunciado por atitudes cometidas, reflete Maquiavel. Mas pode ser que esse alguém possa justificar-se ou ser justificado pelos resultados dessas mesmas atitudes, "... quando o resultado for bom, como no exemplo de Rômulo (...). Só devem ser reprovadas as ações cuja violência tem por objetivo destruir, em vez de reparar. (...) O que demonstra que Rômulo merece ser absolvido da morte do seu irmão e do seu colega, e que agiu não para satisfazer uma ambição pessoal, mas em prol do bem comum (...)".56 Para Wolin, sua originalidade está mais na exclusão de temas não-políticos como, por exemplo, a hostilidade de Maquiavel contra os governantes hereditários e seu profundo desprezo pela nobreza. ${ }^{57}$ Sem dúvida, tal omissão é também um elemento de originalidade. E isso porque a tratadística política da época, e do período posterior, jamais passou ao largo desses objetos.

\footnotetext{
${ }^{55}$ Cf. BERLIN, Isaiah. «La originalidad de Maquiavelo». In: —. Op. cit., p. 117.

${ }^{56}$ Maquiavel, Nicolau. Comentários sobre a Primeira Década de Tito Lívio. Op. cit., p. 49s.

${ }^{57}$ Cf. Wolin, Sheldon. Op. cit., p. 214s.
} 
As redescrições maquiavelianas foram capazes de enunciar aquilo que certos pensadores políticos já haviam percebido: as relações entre os homens e, sobretudo, entre os Estados, não podem ser reguladas segundo preceitos religiosos e normas evangélicas. Como avaliou Berlin, Maquiavel não se recusava a reconhecer a santidade dos santos. Apenas constatou que as suas virtudes não bastavam para sustentar a ordem requerida a um corpo político. ${ }^{58}$ Quanto a esse aspecto, talvez sejam pertinentes e complementares as observações de David Hume acerca de um, por assim dizer, "duplo" Maquiavel. Diz o filósofo escocês que

"O próprio Maquiavel demonstra um autêntico sentimento de virtude em sua história de Florença. Quando ele fala como um Político, em seus raciocínios gerais, ele considera o envenenamento, o assassinato e o perjúrio como meios lícitos do exercício do poder; mas, quando fala como um Historiador, em suas narrativas particulares, ele demonstra uma indignação tão intensa contra o vício e uma aprovação tão vigorosa da virtude, em muitas passagens, que eu não hesitaria em aplicar a ele aquela observação de Horácio: Que, se você perturba a natureza, ainda que com grande indignação, ela sempre se voltará contra você". ${ }^{59}$

Ele não renegava a religião, porque sabia de sua importância na condução de um rebanho que, com frequência, podia se mostrar instável. Então, a carência natural de juízo crítico por parte da multidão poderia se transformar numa verdadeira benção para o governante. Afinal, se a política é criação de força afirmada por ações intrépidas dos grandes homens, também é composta pela teatralização do poder, que consiste em manipular algumas essências em meio a um complicado jogo de aparências. Renegar ou se contrapor a artigos de fé há muito consolidados pela tradição religiosa não era atitude recomendável. O motivo é elementar: o fascínio que exercem esses artigos sobre o espírito das massas.

Se, de fato, a concepção essencialmente empírica que Maquiavel desenvolveu acerca da política foi bastante hostil ao cristianismo dos clérigos - responsável por gerar cidadãos degenerados —, ela não é necessariamente anti-religiosa. Para ser positivo, o cristianismo deveria ser uma religião cívica; a Igreja teria deformado as suas virtudes originais e lhe sangrado em seus princípios vitais. E o historiador de Florença afirmou convictamente que, quem desejasse salvar sua alma, não poderia servir ao Estado, ao menos da forma como era necessário.

\footnotetext{
${ }^{58}$ Cf. BerLIN, Isaiah. «La originalidad de Maquiavelo». In: —_. Op. cit., p. 110s.

${ }^{59}$ Hume, David. «Do estudo da história». In: ——. Ensaios morais, políticos \& literários. Op. cit., p. 786.
} 
Desse modo, Maquiavel subordinou os princípios da moral cristã à política. Esses passaram a ser empregados apenas em certas circunstâncias. Nesse caso, subordinar não significa exatamente submeter, mas antes "separar" ou "distinguir", para alcançar um efeito compensador à lógica da razão de Estado formulada. Ele não submeteu a moral à política. Ele se propôs a identificar as normas objetivas dessa última. Maquiavel ampliou o conceito de virtù já utilizado em sua época para exaltar a força e o talento de alguns indivíduos notáveis. Para ele, que sempre se considerou conselheiro dos príncipes, a principal preocupação devia ser a de tornar possível a estes personagens alcançar o que desejassem. O realismo de Maquiavel é o ponto culminante de uma larga tradição de manuais para monarcas e de descrições de Estados ideais. ${ }^{60}$ Esse fascínio de Maquiavel pela realeza heróica por oposição à realeza hereditária — é ainda melhor traduzido, a propósito de um outro antigo personagem. Segundo Maquiavel, Hiero de Siracusa havia sido um político tão formidável que, ainda na condição de um simples particular, dizia-se que nada lhe faltava para reinar, a não ser um reino. Se, para Maquiavel, o Estado é mesmo obra de arte do príncipe, daí advém a admiração devotada aos "canteiros de obras" representados pelos principados em construção, em detrimento dos edifícios já construídos, ou seja, os Estados dinásticos consolidados, como ele expressou notadamente nos primeiros parágrafos de $O$ Príncipe.

Por meio de histórias repletas de ações heróicas de grandes personagens históricos ou até mesmo lendários, Maquiavel celebrou o valor intrínseco das ações humanas. Utilizando-se de suas célebres e por que não dizer desconcertantes redescrições morais, o historiador de Florença transgrediu vigorosamente a tradição cristã do pensamento político. Suas fluidificações conceituais foram responsáveis pela volatilização de noções muito rígidas, que opunham o bem e o mal como esferas incompatíveis e/ou inconciliáveis.Ele as fez refluir à condição de regiões carentes de fronteiras perceptíveis. Aliás, ele insistiu nas interfaces de tais regiões. Ao situar o homem diante de condições controláveis por si mesmo, seu realismo político favoreceu a proliferação de gerações e gerações de vociferantes contestadores, ao passo que seus admiradores e defensores declarados sempre foram infinitamente mais tímidos e mais escassos. Os homens são predominantemente maus, acreditava Maquiavel, constituindo-se essa diretriz de pensamento numa realista e, porque não dizer, honesta reação aos moralismos de sua época. Por tal ângulo, o maquiavelismo político pode ser representado como a corrente transmissora de uma tensão nova na história da teoria política moderna porque, fundamentalmente, consistiu numa tomada radical de consciência da autonomia do homem em conduzir o curso da história de acordo apenas com sua

${ }^{60}$ Cf. REXROTH, Kenneth. Op. cit., p. 151. 
própria vontade. Se de fato "ao homem é dado ser tudo o que quiser e ter tudo o que desejar", a máxima do célebre humanista Pico della Mirandola — se transportada à esfera das ações políticas -, talvez se preste a traduzir o que há de essencial no realismo radical do historiador de Florença.

\section{BIBLIOGRAFIA}

ArON, Raymond. L'opium des intellectuels. Paris: Gallimard, 1968.

BERLIN, Isaiah. «La originalidad de Maquiavelo». In: ——. Contra la corriente. Ensayos sobre historia de las ideas. México: FCE, 1992.

BIGNOTTO, Newton. «Natureza humana e história». In: —. Maquiavel republicano. São Paulo: Loyola, 1991.

Bossuet, Jacques-Bénigne. Discours sur l'Histoire Universel. Paris: Flammarion, 1920.

Bossuet, Jacques-Bénigne. Politique tirée des propres paroles de l'Ecriture Sainte. Genève, Droz, 1967.

BossuET, Jean-Bénigne. Orações fúnebres e panegyricos. Rio de Janeiro, H. Garnier, 1909. (Organização e apresentação de Louis Moland).

CANTARINO, Elena. «Tratadistas político-morales de los siglos XVI y XVII: apuntes sobre el estado actual de la investigación». El Basilisco. Revista de Filosofía, Ciencias Humanas, Teoria de la Ciencia y de la Cultura. Oviedo, 21, 1996.

CASSIRER, Ernst. O mito do Estado. São Paulo: Códex, 2003.

Chrisholm, Robert. "A ética feroz de Maquiavel». In: QuiRINo, Célia. et alii. (Org.). Clássicos do pensamento político. São Paulo: Edusp/Fapesp, 1998.

Collingwood, Robin George. «Os historiadores do Renascimento». In: — . A ideia de história. Lisboa: Presença, 1981.

DE GRAZIA, Sebastian. «O espelho do príncipe novo». In: —. Maquiavel no inferno. São Paulo: Companhia das Letras, 2000.

FUETER, Eduard. «La nueva historiografía política de Florencia a comienzos del siglo XVI». In: —. Historia de la historiografía moderna. Buenos Aires: Editorial Nova, 1953. Vol. 02.

GETTELL, Raymond. História das ideias políticas. Lisboa: Editorial Inquérito, 1950.

GRANADA, Miguel. Cosmologia, religión y política en el Renacimiento. Barcelona: Anthropus, 1988.

HoBbeS, Thomas. Do cidadão. São Paulo: Martins Fontes, 2002.

KoYRÉ, Alexandre. Estudos de história do pensamento científico. Brasília: Editora UnB, 1982.

LA BRUYÈrE, Jean de. Les caractères ou les moeurs de ce siècle. Paris: Hachette, 1890.

LA RochefouCAULD. Máximas e reflexões. Rio de Janeiro: Imago, 1994.

LARIVAILLE, Paul. «O caso Maquiavel ou o intelectual frente ao poder». In: — . A Itália no tempo de Maquiavel. São Paulo: Companhia das Letras, 1988.

LoUIS XIV. Mémoires. Paris: LCL, 1960.

MAQUIAVEL, Nicolau. «Do modo de tratar os povos rebelados do vale do Chiana». In: . Escritos Políticos. São Paulo: Abril Cultural, 1973. (Coleção Os pensadores).

MAQUIAVEL, Nicolau. A arte da guerra e outros ensaios. Brasília: Editora UnB, 1982. 
Impiedades reveladas: histórias de valores morais e políticos para exemplo e proveito dos...

Maquiavel, Nicolau. Comentários sobre a Primeira Década de Tito Lívio. Brasília: Editora UnB, 1979.

MAQuiAvel, Nicolau. Epistolário. México: FCE, 1993.

MAquiAVel, Nicolau. Maquiavel, O Príncipe - Estudos. Brasília: Editora UnB, 1982.

MARIANA, Juan de. Del rey y de la institucion de la dignidad real. Buenos Aires, Editorial Partenón, 1945.

MAYER, J.P. Trayectoria del pensamiento político. México: FCE, $1985 .$.

MAZARINO. Breviário dos políticos. Brasília: Alhambra, s/d.

PERRY, Marvin. Civilização Ocidental: uma história concisa. São Paulo: Martins Fontes, 1999.

PoMEAU, René. «Présentation». In: ——. Politique de Voltaire. Paris: Armand Colin, 1994.

ReXROTH, Kenneth. Recordando a los clásicos. México: Fondo de Cultura Económica, 1993.

RICHELIEU. «Testament politique». In: GAUCHERON, Roger. (Org.). Oeuvres du Cardinal de Richelieu. Paris: Plon, 1933.

RIDOLFI, Roberto. «Nicolau Maquiavel, historiador». In: —. Biografia de Nicolau Maquiavel. São Paulo: Musa Editora, 2003.

Romano, Ruggiero. \& TENENTI, Alberto. Los fundamentos del mundo moderno. Madrid: Siglo XXI, 1972.

ROTERDÃ, Erasmo. de. Institución del príncipe cristiano. Madrid: Tecnos, 1994.

SAAVEDRA FAJARDO, Diego de. (1964). Ideal de um príncipe político cristão. São Paulo: Gráfica Editora Brasileira.

SABINE, George. História das Teorias Políticas. Rio de Janeiro: Editora Fundo de Cultura, 1964. (Vol. 01).

SKINNER, Quentin. «O historiador de Florença». In: —. Maquiavel. Porto Alegre: L\&PM, 2010.

SKINNER, Quentin. As fundações do pensamento político moderno. São Paulo: Companhia das Letras, 1996.

SKINNER, Quentin. Razão e retórica na filosofia de Hobbes. São Paulo: Editora Unesp, 1999.

Strauss, Leo. What is Political Philosophy? New York: Free Press, 1968.

Wolin, Sheldon. Política y perspectiva. Continuidad y cambio em el pensamiento político occidental. Buenos Aires: Amorrortu Editores, 1973. 
